Cat i oni c NRL4 Cages for Perchl or at e Renmval from Aqueous Sol uti ons and Pref er ent $i$ al Perchl or at e I ncorporat i on in Hydrophi I i c Sol ut i ons

\begin{tabular}{|c|c|}
\hline 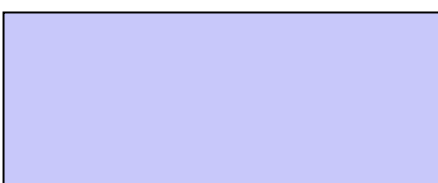 & $\begin{array}{l}\text { Sone Eri ko, Sat o Nbeko, Mochi zuki Masar u, } \\
\text { Kami o Chi hi r o, Yamani shi Kat sunori, Kondo } \\
\text { M t sur u }\end{array}$ \\
\hline $\begin{array}{l}\text { j our nal or } \\
\text { publ i cat i on } \mathrm{title}\end{array}$ & Cr yst EngComm \\
\hline vol une & 18 \\
\hline nunber & 26 \\
\hline page $r$ ange & 50045011 \\
\hline year & 2016-03-28 \\
\hline 出版者 & Royal Sci ety of Chemistry \\
\hline 権利 & (C) Royal Soci ety of Chem st ry 2017 \\
\hline URL & ht t p: //hdl . handl e. net /10297/10105 \\
\hline
\end{tabular}




\title{
Cationic $\mathbf{M}_{2} \mathrm{~L}_{4}$ Cages for Perchlorate Removal from Aqueous Solutions and Preferential Perchlorate Incorporation in Hydrophilic Solutions
}

\author{
Eriko Sone, ${ }^{1}$ Moeko Sato, ${ }^{1}$ Masaru Mochizuki, ${ }^{1}$ Chihiro Kamio, ${ }^{1}$ Katsunori Yamanishi, $\ddagger^{2}$ \\ and Mitsuru Kondo*,1,3
}

${ }^{1}$ Department of Chemistry, Faculty of Science, Shizuoka University, 836 Ohya, Suruga-ku, Shizuoka, 422-8529, Japan

${ }^{2}$ Graduate School of Science and Technology, Shizuoka University, 836 Ohya, Suruga-ku, Shizuoka, 422-8529, Japan

3 Research Institute of Green Science and Technology, Shizuoka University, 836 Ohya, Suruga-ku, Shizuoka 422-8529, Japan

E-mail: kondo.mitsuru@shizuoka.ac.jp

$\dagger$ Electronic supplementary information (ESI) available: Figure S1-S2 show the crystal structures of $\mathbf{1 a}, \mathbf{1} \boldsymbol{b}, \mathbf{2} \boldsymbol{a}$, and $\mathbf{2 b}$; Figure S3 shows anion removal chart by $\mathbf{1 b}$. CCDC 1451229 (1a), 1451228 (1b), 1451231 (2a), and 1451230 (2b). Crystallographic data in CIF or other electronic format see DOI:

$\$$ Present address: Institute for Molecular Science, Okazaki, Aichi 444-8787, Japan

\begin{abstract}
Four new cage-type compounds, $\left[\mathrm{A} \subset \mathrm{Cu}_{2}(m \text {-bbitrb })_{4}\right] \mathrm{A}_{3}\left(\mathrm{~A}=\mathrm{Cl}^{-}(\mathbf{1 a}), \mathrm{Br}^{-}(\mathbf{1 b})\right.$, $m$-bbitrb $=$ 1,3-bis(benzimidazol-1-ylmethyl)-2,4,6-trimethylbenzene), and $\left[\mathrm{SO}_{4} \subset\right.$ $\left.\mathrm{Cu}_{2}(m \text {-bbitrb })_{4}\right] \mathrm{A}_{2} \quad\left(\mathrm{~A}=\mathrm{Cl}^{-}(\mathbf{2 a}), \mathrm{Br}^{-}(\mathbf{2} \mathbf{b})\right)$, were synthesized and characterized. These compounds have a $\mathrm{M}_{2} \mathrm{~L}_{4}$-type cationic cage, incorporating an anion in the cage. Although the four compounds are insoluble in water, they exhibit $\mathrm{ClO}_{4}^{-}$removal activity from aqueous solutions by exchange with anions located outside the cage. The $\left[\mathrm{Cl} \subset \mathrm{Cu}_{2}(m \text {-bbitrb })_{4}\right]^{3+}$ cage removes $\mathrm{ClO}_{4}{ }^{-}$from aqueous solutions preferentially. To study the selective removal process by the cationic cage, the affinity of the $\left[\mathrm{Cu}_{2}(m \text {-bbitrb })_{4}\right]^{4+}$ cage for $\mathrm{ClO}_{4}^{-}$was studied by measuring solid-state reflectance spectra, absorption spectra, and ESI-TOF mass spectra in solutions of $\mathrm{MeCN}$ and $\mathrm{MeCN} / \mathrm{H}_{2} \mathrm{O}$ for $\left[\mathrm{SO}_{4} \subset \mathrm{Cu}_{2}(m \text {-bbitrb })_{4}\right]\left(\mathrm{ClO}_{4}\right)_{2}(\mathbf{2 d})$. Results indicated that the $\mathrm{SO}_{4}{ }^{2-}$ in $\left[\mathrm{SO}_{4} \subset \mathrm{Cu}_{2}(m \text {-bbitrb })_{4}\right]^{2+}$ was retained in $\mathrm{MeCN}$ solution, whereas in $\mathrm{MeCN} / \mathrm{H}_{2} \mathrm{O}$ solution the $\mathrm{SO}_{4}{ }^{2-}$ was exchanged with the $\mathrm{ClO}_{4}{ }^{-}$located outside the cage. This is because an increase in the hydrophilicity of the solution promotes the incorporation of hydrophobic $\mathrm{ClO}_{4}^{-}$into the
\end{abstract}


hydrophobic cage, meaning that the preferential removal of $\mathrm{ClO}_{4}{ }^{-}$from aqueous solutions is due to the higher affinity of the hydrophobic space created outside the $\mathrm{M}_{2} \mathrm{~L}^{\mathrm{B}}{ }_{4}$ cages in the solid state.

\section{Introduction}

Many cage-type coordination compounds have attracted great attention as molecular capsules to recognize and separate target molecules or ions. ${ }^{1-16}$ Many metal complexes provide various cage frameworks. Coordination bonds between metal ions and organic bridging ligands generally construct these frameworks. When the cages are constructed by metal ions and neutral organic bridging ligands, the obtained coordination cages have positive charges, which are useful for the trapping of anions. ${ }^{17}$

Flexible bis-imidazole- and bis-benzimidazole-type neutral ligands, designated as $\mathrm{L}^{\mathrm{B}}$, have yielded many cage-type coordination compounds such as $\mathrm{M}_{2} \mathrm{~L}^{\mathrm{B}}{ }_{4},{ }^{5,18-23} \mathrm{M}_{2} \mathrm{~L}_{3}{ }_{3},{ }^{5} \mathrm{M}_{3} \mathrm{~L}^{\mathrm{B}}{ }_{4},{ }^{24,25}$ and $\mathrm{M}_{4}(\mu-\mathrm{OR})_{4} \mathrm{~L}^{\mathrm{B}}{ }_{4}$ frameworks. ${ }^{26}$ Among them, the $\mathrm{M}_{2} \mathrm{~L}^{\mathrm{B}}{ }_{4}$ cages have generally been isolated with an anion trapped in the cationic cages. The following bridging ligands have often been used for the synthesis of $\mathrm{M}^{\mathrm{II}} \mathrm{L}^{\mathrm{B}}{ }_{4}$ cage-type compounds: 1,3-bis(benzimidazol-1-ylmethyl)-2,4,6-trimethylbenzene (m-bbitrb), 1,4-bis(benzimidazol-1-ylmethyl)-2,3,5,6-tetramethylbenzene (p-bbiteb), 1,3-bis(imidazol-1-ylmethyl)-2,4,6-tetramethylbenzene (m-bitrb), and 1,4-bis(imidazol-1-ylmethyl)-2,3,5,6-tetramethylbenzene ( $p$-biteb) (Scheme 1).

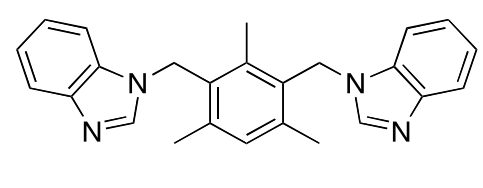

$m$-bbitrb<smiles>Cc1cc(C)c(Cn2ccnc2)c(C)c1Cn1ccnc1</smiles>

m-bitrb

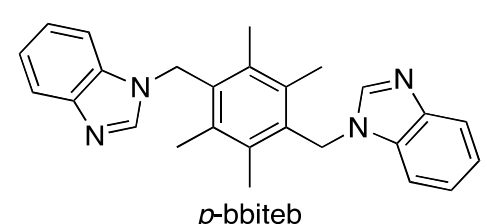

p-bbiteb

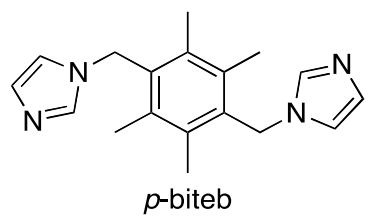

Scheme 1. Ligand structures.

The perchlorate ion $\left(\mathrm{ClO}_{4}^{-}\right)$is highly toxic, particularly in infants and children, because ingestion of this anion disturbs the uptake of iodine by the thyroid gland, inhibiting the formation of growth hormone. ${ }^{27-29}$ Nevertheless, this anion has often been detected, worldwide, in environmental water, agricultural products, and tap water used for drinking. ${ }^{29-33}$ Therefore, 
the development of methods for $\mathrm{ClO}_{4}{ }^{-}$removal from aqueous solutions constitutes an important subject in the field of host-guest chemistry as well as in environmental science. ${ }^{34}$

The host materials that capture the target anions selectively are known as anion hosts. Their host frameworks usually recognize the target anions by forming hydrogen bonds and/or coordination bonds with the target anions. ${ }^{17}$ However, recognition of $\mathrm{ClO}_{4}{ }^{-}$by anion hosts is quite difficult because of the remarkably low ability of this anion to form chemical bonds. ${ }^{35}$

Previously, we investigated $\mathrm{ClO}_{4}^{-}$removal methods by using cationic $\mathrm{Cu}_{2}{ }_{2} \mathrm{~L}_{4}{ }_{4}$ cages. ${ }^{21-23,} 36$ We have shown, for example, that $\mathrm{ClO}_{4}{ }^{-}$is removed from aqueous solutions preferentially by formation of the water-insoluble cage-type compound $\left[\mathrm{ClO}_{4} \subset\right.$ $\left.\mathrm{Cu}_{2}(p \text {-biteb })_{4}\left(\mathrm{ClO}_{4}\right)_{2}\right] \mathrm{ClO}_{4}{ }^{21}$ We also found that the water-insoluble $\mathrm{M}_{2} \mathrm{~L}^{\mathrm{B}}$-type compound $\left[\mathrm{SO}_{4} \subset \mathrm{Cu}_{2}(m \text {-bbitrb })_{4}\right] \mathrm{SO}_{4}(\mathbf{2 c})$ removes $\mathrm{ClO}_{4}^{-}$from aqueous solutions by anion-exchange reactions. In this treatment, the $\mathrm{SO}_{4}{ }^{2-}$ in the cage remains after the reactions. ${ }^{23}$ More recently, we have shown that $2 \mathrm{D}$ coordination polymers bearing cationic $\mathrm{Cu}^{\mathrm{II}}{ }_{2} \mathrm{~L}_{4}$ cages on the $2 \mathrm{D}$ framework remove $\mathrm{ClO}_{4}{ }^{-}$preferentially by anion-exchange reactions. ${ }^{36}$ These previous studies have shown that the water-insoluble cationic $\mathrm{M}_{2} \mathrm{~L}^{\mathrm{B}}{ }_{4}$ cages are useful cationic units for the removal of $\mathrm{ClO}_{4}^{-}$.

In this work, we have synthesized four new $\mathrm{M}_{2} \mathrm{~L}^{\mathrm{B}}{ }_{4}$ cage-type compounds $[\mathrm{A} \subset$ $\left.\mathrm{Cu}_{2}(m \text {-bbitrb })_{4}\right] \mathrm{A}_{3}(\mathrm{~A}=\mathrm{Cl}(\mathbf{1 a}), \mathrm{Br}(\mathbf{1 b}))$ and $\left[\mathrm{SO}_{4} \subset \mathrm{Cu}_{2}(m \text {-bbitrb })_{4}\right] \mathrm{A}_{2}(\mathrm{~A}=\mathrm{Cl}(\mathbf{2 a}), \mathrm{Br}(\mathbf{2 b}))$, and characterized the removal of $\mathrm{ClO}_{4}^{-}$from aqueous solutions. The effect of solvent on the affinity of the cationic cage $\left[\mathrm{Cu}_{2}(m \text {-bbitrb })_{4}\right]^{4+}$ for $\mathrm{ClO}_{4}^{-}$was also investigated during the study of the $\mathrm{ClO}_{4}{ }^{-}$removal process by the $\mathrm{M}_{2} \mathrm{~L}^{\mathrm{B}}{ }_{4}$-type cage. This paper describes the syntheses, structures, and the anion-inclusion properties of the $\left[\mathrm{Cu}_{2}{ }_{2}(m \text {-bbitrb })_{4}\right]^{4+}$ cages.

\section{Experimental}

General. All chemicals and organic solvents were purchased from commercial sources and used without further purification. The ligand $m$-bbitrb was prepared according to a literature method. Compounds $\left[\mathrm{ClO}_{4} \subset \mathrm{Cu}_{2}(m \text {-bbitrb })_{4}\left(\mathrm{ClO}_{4}\right)_{2}\right]\left(\mathrm{ClO}_{4}\right),{ }^{5} \mathbf{2} \mathbf{c},{ }^{23}$ and $\mathbf{2} \mathbf{d}^{23}$ were prepared according to previously reported methods. IR spectra were recorded on a Shimadzu IR Affinity-1 FT-IR spectrophotometer, using $\mathrm{KBr}$ pellets. Solid-state reflectance spectra and absorption spectra were recorded on a Jasco V-570 spectrophotometer. Elemental analyses were measured using a Euro Vector EA3000 elemental analyzer. The electrospray ionization time-of-flight (ESI-TOF) mass spectra were recorded on a Jeol JMS-T100LP mass spectrometer, using a positive-mode ESI-TOF method. Samples were eluted with a mobile phase comprising $\mathrm{MeCN}$ or $\mathrm{MeCN} / \mathrm{H}_{2} \mathrm{O}$ mixed solvent $\left(\mathrm{MeCN} / \mathrm{H}_{2} \mathrm{O}\right)$.

Caution: Although we experienced no difficulties while working with the perchlorate salts, they should be regarded as potentially explosive and handled with care. 
Synthesis of $\left[\mathrm{Cl} \subset \mathrm{Cu}_{2}(m \text {-bbitrb })_{4}\left(\mathrm{H}_{2} \mathrm{O}\right)_{2}\right] \mathrm{Cl}_{3}$ (1a). An aqueous solution $(10 \mathrm{~mL})$ of $\mathrm{CuCl}_{2} \cdot 2 \mathrm{H}_{2} \mathrm{O}(25.6 \mathrm{mg}, 0.15 \mathrm{mmol})$ was mixed with an EtOH solution $(10 \mathrm{~mL})$ of $m$-bbitrb $(114.1 \mathrm{mg}, 0.30 \mathrm{mmol})$. The solution was left to stand without stirring for two weeks. This yielded blue crystals. One of the crystals was used for the X-ray crystal structure determination study; the residual crystals were used for other measurements. Yield: $103 \mathrm{mg}$ (75.3\%). Anal. Calcd for $\mathrm{C}_{100} \mathrm{H}_{100} \mathrm{Cl}_{4} \mathrm{Cu}_{2} \mathrm{~N}_{16} \mathrm{O}_{2}$ : C, 65.74; H, 5.52; N, 12.27. Found: C, 65.72; H, 5.30; N, 12.16 . IR (KBr, cm ${ }^{-1}$ ): 3410 (m), 3119 (w), 3059 (w), 3017 (w), 2993 (w), 2920 (w), 1614 (s), 1591 (w), (s), 1481 (s), 1464 (s), 1394 (m), 1329 (m), 1294 (m), 1254 (m), 1233 (s), 1200 (w), 1184 (w), $1126(\mathrm{w}), 1092(\mathrm{w}), 1036(\mathrm{~m}), 1011(\mathrm{~m}), 920(\mathrm{~m}), 889(\mathrm{w}), 841(\mathrm{~m}), 750(\mathrm{~s}), 691(\mathrm{w}), 646$ (w), $623(\mathrm{~m}), 604(\mathrm{~m}), 511(\mathrm{~m}), 461(\mathrm{~m})$.

Synthesis of $\left[\mathrm{Br} \subset \mathrm{Cu}_{2}(m \text {-bbitrb })_{4}\left(\mathrm{H}_{2} \mathrm{O}\right)_{2}\right] \mathrm{Br}_{3}(\mathbf{1 b})$. An EtOH solution $(30 \mathrm{~mL})$ of $m$-bbitrb (110 mg, $0.30 \mathrm{mmol})$ was slowly added to an aqueous solution $(30 \mathrm{~mL})$ of $\mathrm{CuBr}_{2}(33$ $\mathrm{mg}, 0.15 \mathrm{mmol}$ ) and left to stand for a few weeks. This yielded blue-plate crystals. One of the crystals was used for the X-ray crystal structure determination study; the residual crystals were used for other measurements. Yield: $116 \mathrm{mg}$ (78.8\%). Anal. Calcd for $\mathrm{C}_{100} \mathrm{H}_{96} \mathrm{Br}_{4} \mathrm{Cu}_{2} \mathrm{~N}_{16}$ : C, 61.01; H, 4.92; N, 11.38. Found: C, 61.02; H, 4.60; N, 11.40. IR (KBr, cm $\left.{ }^{-1}\right): 3356$ (w), 2970 (w), 2908 (w), $1612(\mathrm{~m}), 1517$ (s), 1479 (s), 1462 (s), 1398 (m), 1327 (w), 1292 (m), 1232 (s), 1195 (m), 1182 (m), 1012 (w), 921 (w), 576 (w), 480 (w), 428 (w).

Synthesis of $\left[\mathrm{SO}_{4} \subset \mathbf{C u}_{2}(\boldsymbol{m} \text {-bbitrb) })_{4}\right] \mathbf{C l}_{2} \cdot \mathbf{H}_{2} \mathbf{O}(\mathbf{2 a})$. An EtOH solution $(20 \mathrm{~mL})$ of $m$-bbitrb (110 mg, $0.30 \mathrm{mmol})$ was mixed with an aqueous solution $(30 \mathrm{~mL})$ of $\mathrm{CuSO}_{4} \cdot 5 \mathrm{H}_{2} \mathrm{O}$ $(37.5 \mathrm{mg}, 0.15 \mathrm{mmol})$ and an $\mathrm{EtOH} / \mathrm{H}_{2} \mathrm{O}(1 / 1 ; \mathrm{v} / \mathrm{v})$ solution $(30 \mathrm{~mL})$ of $\mathrm{NaCl}(8.0 \mathrm{mg}, 0.15$ $\mathrm{mmol})$. The solution was left to stand without stirring for two weeks. This yielded blue-block crystals. Yield: $91.2 \mathrm{mg}$ (68.1\%). Anal. Calcd for $\mathrm{C}_{100} \mathrm{H}_{98} \mathrm{Cl}_{2} \mathrm{Cu}_{2} \mathrm{~N}_{16} \mathrm{O}_{5} \mathrm{~S}$ : C, 65.49; H, 5.39; N, 12.22. Found: C, 65.56; H, 5.19; N, 12.34. IR $\left(\mathrm{KBr}, \mathrm{cm}^{-1}\right): 3342$ (w), 3064 (w), 2972 (w), 1612 (w), $1516(\mathrm{w}), 1463$ (s), $1402(\mathrm{~m}), 1388(\mathrm{w}), 1296(\mathrm{~m}), 1236(\mathrm{w}), 1203(\mathrm{~m}), 1138(\mathrm{~m}), 1107$ (m), 1083 (m), 1043 (m), 1010 (w), 920 (w), 744 (s), 611 (w), 480 (w), 418 (m).

Synthesis of $\left[\mathbf{S O}_{4} \subset \mathbf{C u}_{2}(\boldsymbol{m} \text {-bbitrb })_{4}\right] \mathrm{Br}_{2} \cdot \mathbf{H}_{2} \mathrm{O}(\mathbf{2 b})$. An EOH solution $(20 \mathrm{~mL})$ of $m$-bbitrb (114 mg, $0.30 \mathrm{mmol})$ was added to an aqueous solution $(20 \mathrm{~mL})$ of $\mathrm{CuSO}_{4} \cdot 5 \mathrm{H}_{2} \mathrm{O}(37.5$ $\mathrm{mg}, 0.15 \mathrm{mmol})$ and an $\mathrm{EtOH} / \mathrm{H}_{2} \mathrm{O}$ solution of $\mathrm{NaBr}(15.4 \mathrm{mg}, 0.15 \mathrm{mmol})$. The resulting mixture was left to stand at room temperature for several days. This yielded blue-block crystals (100 mg, 69.5\%). Anal. Calcd for $\mathrm{C}_{100} \mathrm{H}_{98} \mathrm{Cu}_{2} \mathrm{Br}_{2} \mathrm{~N}_{16} \mathrm{O}_{5} \mathrm{~S}: \mathrm{C}, 62.46 ; \mathrm{H}, 5.14 ; \mathrm{N}, 11.65$. Found: $\mathrm{C}$, 62.44; H, 5.13; N, 11.17. IR (KBr, cm $\left.{ }^{-1}\right) 3375$ (w), 3053 (m), 3018 (m), 2968 (w), 2954 (w), 1614 (w), 1514 (s), 1465 (s), 1402 (m), 1330 (w), 1298 (m), 1236 (m), 1215 (m), 1186 (w), 1143 (m), 1105 (m), 1083 (w), 1053 (s), 1012 (w), 920 (m), 763 (m), 742 (s), 615 (w), 476 (w), 428 (w). This compound was also obtained by treatment of $2 \mathrm{c}$ with excess $\mathrm{NaBr}$. An EtOH solution $(20 \mathrm{~mL})$ of $\mathbf{2 c}(199 \mathrm{mg}, 0.10 \mathrm{mmol})$ and an aqueous solution $(20 \mathrm{~mL})$ of $\mathrm{NaBr}(206 \mathrm{mg}$, 
$2.00 \mathrm{mmol}$ ) were mixed. The solution was exposed to the air to allow slow evaporation. Within a week, blue-plate crystals were obtained (133 mg, 69.4\%). Identification of this compound was carried out by determination of the cell parameters: tetragonal, $a=b=16.920$ (5) $\AA, c=32.49$ (1) $\AA, V=9301.9(4) \AA^{3}$.

Crystal structure determination. A single crystal of each compound was sealed in a glass capillary with its mother liquid. Data collection was carried out on a Rigaku CCD Mercury system fitted with a monochromatic MoKa radiation source $(\lambda=0.71069 \AA)$. Data from the X-ray measurements are summarized in Table 1. Eighteen preliminary data frames were measured at $0.5^{\circ}$ increments of $\omega$ to assess the crystal quality and preliminary unit cell parameters. The intensity images were also measured at $0.5^{\circ}$ intervals of $\omega$. The intensity images were integrated using the CrystalClear program package, and the empirical absorption correction was applied for the data. The structures were solved by direct methods, SHELX-97, and refined using the SHELXL-97 (1a, 1b, and 2b) or SHELXL2013 (2a) programs. The crystallographic parameters are summarized in Table 1.

Anion removal experiments. For the $\mathrm{ClO}_{4}{ }^{-}$removal from an aqueous solution experiment, an aqueous solution of $\mathrm{ClO}_{4}^{-}(1.0 \mathrm{mM})$ was prepared by dissolving $\mathrm{NaClO}_{4}(30.6$ $\mathrm{mg}, 0.25 \mathrm{mmol})$ in ultrapure water $(250 \mathrm{~mL})$. A $100 \mathrm{~mL}$ volume of this solution was transferred to another vessel containing $0.1 \mathrm{mmol}$ of the cage-type compound. The vessel was capped with a rubber septum and then shaken $(100 \mathrm{rpm})$ in a water bath at $30{ }^{\circ} \mathrm{C}$. Changes in the concentrations of the anions in the solution over time were monitored by ion chromatography analysis of the solution. Samples for analysis were prepared by dilution of $200 \mu \mathrm{L}$ aliquots of the reaction solution into $4800 \mu \mathrm{L}$ of the ultrapure water. Concentrations of the anions in the aqueous solutions were determined using a Metrohm Compact IC 861 ion chromatography instrument. Other anion removal experiments were carried out using a similar procedure. 
Table 1. Crystallographic data for 1a, 1b, 2a, and $\mathbf{2 b}$

\begin{tabular}{|c|c|c|c|c|}
\hline complexes & 1a & $1 b$ & $\mathbf{2 a}$ & $2 \mathbf{b}$ \\
\hline formula & $\mathrm{C}_{100} \mathrm{H}_{100} \mathrm{Cl}_{4} \mathrm{Cu}_{2} \mathrm{~N}_{16} \mathrm{O}_{2}$ & $\mathrm{C}_{100} \mathrm{H}_{100} \mathrm{Br}_{4} \mathrm{Cu}_{2} \mathrm{~N}_{16} \mathrm{O}_{2}$ & $\mathrm{C}_{100} \mathrm{H}_{98} \mathrm{Cl}_{2} \mathrm{Cu}_{2} \mathrm{~N}_{16} \mathrm{O}_{5} \mathrm{~S}$ & $\mathrm{C}_{100} \mathrm{H}_{98} \mathrm{Br}_{2} \mathrm{Cu}_{2} \mathrm{~N}_{16} \mathrm{O}_{5} \mathrm{~S}$ \\
\hline fw & 1826.90 & 2004.70 & 1834.04 & 1922.94 \\
\hline lattice & tetragonal & tetragonal & tetragonal & tetragonal \\
\hline space group & I4/m (No. 87) & I4/m (No. 87) & $P 4 / n c c$ (No. 130) & P4/ncc (No. 130) \\
\hline$a, \AA$ & $15.2312(8)$ & $15.3248(10)$ & $16.689(4)$ & $16.918(2)$ \\
\hline$c, \AA$ & $23.338(2)$ & $23.354(3)$ & $32.737(8)$ & $32.534(5)$ \\
\hline$V, \AA^{3}$ & $5414.2(7)$ & $5484.6(8)$ & $9118(4)$ & $9312(2)$ \\
\hline$Z$ & 2 & 2 & 4 & 4 \\
\hline$\rho($ calcd $) \mathrm{g} \mathrm{cm}^{-3}$ & 1.121 & 1.214 & 1.336 & 1.372 \\
\hline$\mu(\operatorname{MoK} \alpha), \mathrm{mm}^{-1}$ & 0.542 & 1.899 & 1.836 & 1.402 \\
\hline radiation $(\lambda, \AA)$ & 0.71069 & 0.71069 & 0.71069 & 0.71069 \\
\hline temp, ${ }^{\circ} \mathrm{C}$ & 25 & 25 & 25 & 25 \\
\hline reflns collected & 20493 & 16804 & 57180 & 66405 \\
\hline unique reflns & 2556 & 2398 & 4361 & 5355 \\
\hline$R_{\mathrm{int}}$ & 0.0701 & 0.0805 & 0.1974 & 0.1271 \\
\hline param refined & 175 & 172 & 295 & 304 \\
\hline$R_{1}[I>2 \sigma(\mathrm{I})]$ & 0.0783 & 0.0933 & 0.1463 & 0.0974 \\
\hline $\mathrm{w} R_{2}$ [all data] & 0.0829 & 0.1855 & 0.3398 & 0.1442 \\
\hline GOF on $F^{2}$ & 1.051 & 1.180 & 1.387 & 1.018 \\
\hline
\end{tabular}

\section{Results and discussion}

Syntheses and structures of $1 \mathrm{a}$ and $\mathbf{1 b}$. Compounds $1 \mathrm{a}$ and $\mathbf{1 b}$ were conveniently prepared by the reaction of $\mathrm{CuCl}_{2} \cdot 2 \mathrm{H}_{2} \mathrm{O}$ or $\mathrm{CuBr}_{2}$ with $m$-bbitrb. Figure 1 shows the molecular structure of 1a. The crystallographic $\mathrm{C} 4$ axis runs through the two $\mathrm{Cu}^{\mathrm{II}}$ centers in the cage framework, and the crystallographic mirror exists in the equatorial plane of the cage. Two $\mathrm{Cu}^{\mathrm{II}}$ ions are connected by four $m$-bbitrb to yield the cationic $\mathrm{Cu}_{2}{ }_{2} \mathrm{~L}^{\mathrm{B}}{ }_{4}$ cage, which is similar to the cages of the $\mathrm{M}_{2} \mathrm{~L}^{\mathrm{B}}{ }_{4}$-type compounds previously reported. Compound 1a incorporates a $\mathrm{Cl}^{-}$ inside the cage and has three $\mathrm{Cl}^{-}$outside the cage. The $\mathrm{Cl}^{-}$in the cage is disordered at the six positions, namely, the four crystallographically equivalent positions for $\mathrm{Cl}(1 \mathrm{~A})$ and the two crystallographically equivalent positions for $\mathrm{Cl}(1 \mathrm{~B})$. The occupancies of the $\mathrm{Cl}(1 \mathrm{~A})$ and $\mathrm{Cl}(1 \mathrm{~B})$ were refined as 0.2 and 0.1 , respectively. The $\mathrm{Cl}(1 \mathrm{~A})$ associates with the imidazole hydrogen atom $(\mathrm{Cl}(1 \mathrm{~A}) \cdots \mathrm{H}(1)=$ ca. $2.77 \AA)$ as illustrated in Figure 1b. Although $\mathrm{Cl}(1 \mathrm{~B})$ is located the axial site of the $\mathrm{Cu}(1)$ environment (Figure $1 \mathrm{a}$ and $1 \mathrm{~b}$ ), the interaction with $\mathrm{Cu}(1)$ is weak 
$(\mathrm{Cu}(1)--\mathrm{Cl}(1 \mathrm{~B})=2.97(3) \AA)$.

For the coordination circumstance around the $\mathrm{Cu}^{\mathrm{II}}$ center, a $\mathrm{H}_{2} \mathrm{O}$ molecule outside the cage associates with the metal center $(\mathrm{Cu}(1)---\mathrm{O}(1)=2.637(5) \AA)$ (Figure S1a). This distance is significantly shorter than the $\mathrm{Cu}(1)--\mathrm{Cl}(1 \mathrm{~B})$ distance, but longer than the $\mathrm{Cu}-\mathrm{N}$ bond distances $(\mathrm{Cu}(1)-\mathrm{N}(1)=2.002$ (4) $\AA$ ), giving the distorted square pyramidal or elongated octahedral geometry around the $\mathrm{Cu}^{\mathrm{II}}$ center. One of the counter anions $(\mathrm{Cl}(2))$ located outside the cage is disordered at the four positions by the crystallographic $C 4$ axis. This anion, whose occupancy was refined as 0.25 , bonds with a $\mathrm{H}_{2} \mathrm{O}$ molecule $(\mathrm{O}(1))$ by hydrogen bonding $(\mathrm{Cl}(2) \cdots \mathrm{O}(1)=3.113(12) \AA)$. The other counter anions are located between the cationic cages and have no significant interactions with the cage.

a)

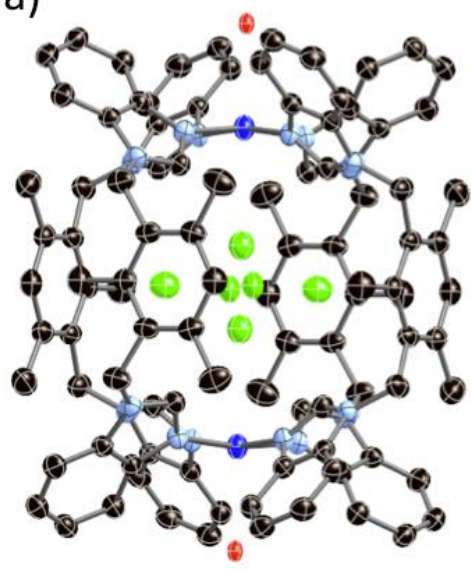

b)

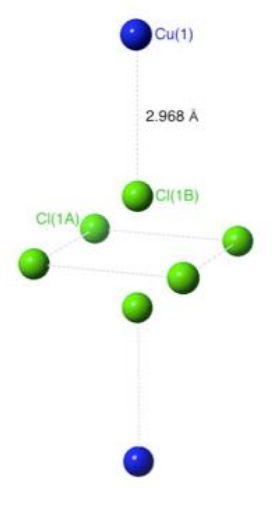

c)

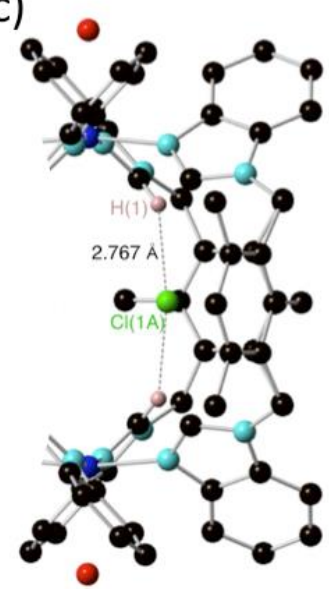

Figure 1. Thermal ellipsoids of the molecular structure of the cationic part of 1a at $30 \%$ probabilities (a), view of the arrangement of the disordered $\mathrm{Cl}^{-}$in the cage (b), and $\mathrm{Cl}^{-} \cdots \mathrm{H}-\mathrm{C}$ interactions for $\mathrm{Cl}(1 \mathrm{~A})$ with an imidazole hydrogen atom (c). Hydrogen atoms, except for $\mathrm{H}(1)$ in (c), are omitted for clarity. Color code: blue, copper; red, oxygen; green, chlorine; cyan, nitrogen; black, carbon.

Compound $\mathbf{1 b}$ crystallized with similar cell parameters and the same tetragonal space group (I4/m, \# 87) as 1a. Although $\mathbf{1 b}$ has a similar structure to that of 1a, the anion disorder inside the cage is significantly different. Figure 2 shows the molecular structure of $\mathbf{1 b}$. This compound also has the crystallographic $\mathrm{C} 4$ axis that runs through the $\mathrm{Cu}(1)$ and $\mathrm{Cu}(2)$ atoms in the cage framework, and the crystallographic mirror in the equatorial plane of the cage. The cationic cage of $\mathbf{1 b}$ contains a $\mathrm{Br}^{-}$, which is disordered at the eight positions (four crystallographically equivalent positions for $\operatorname{Br}(1 \mathrm{~A})$ and four crystallographically equivalent positions for $\operatorname{Br}(1 \mathrm{~B})$ ). The occupancies of the $\operatorname{Br}(1 \mathrm{~A})$ and $\operatorname{Br}(1 \mathrm{~B})$ were refined as 0.14 and 0.11 , 
respectively. The $\mathrm{Br}^{-}$in the eight disordered positions in the cage interacted with an imidazole hydrogen atom $(\operatorname{Br}(1 \mathrm{~A}) \cdots \mathrm{H}(1)=$ ca. $2.80 \AA, \operatorname{Br}(1 \mathrm{~B}) \cdots \mathrm{H}(1)=$ ca. $3.06 \AA)$. In contrast to in $\mathbf{1 a}$, $\mathrm{Br}^{-}$was not observed in the axial position in the coordination environment of the $\mathrm{Cu}^{\mathrm{II}}$ center in $1 \mathrm{~b}$.

As observed in 1a, a water molecule $(\mathrm{O}(1))$ outside the cage associates weakly with the $\mathrm{Cu}^{\mathrm{II}}$ center. The $\mathrm{Cu}---\mathrm{O}$ bond distance $(2.658(10) \AA)$ is close to that of $\mathbf{1 a}$, and significantly longer than that of $\mathrm{Cu}-\mathrm{N}$ bonds $(\mathrm{Cu}(1)-\mathrm{N}(1)=1.992$ (4) $\AA$ ) in the coordination environment. The $\mathrm{Cu}^{\mathrm{II}}$ center is based on the square pyramidal geometry due to the coordinations of four imidazole nitrogen atoms at the basal positions and a water molecule in the apical position. Similar to in 1a, a $\mathrm{Br}^{-}$located outside the cage interacted with the water $(\operatorname{Br}(2 \mathrm{~A}) \cdots \mathrm{O}(1)=3.143$ (9) $\AA$ ) (Figure $\mathrm{S} 1 \mathrm{~b}$ ). $\operatorname{The} \operatorname{Br}(2 \mathrm{~A}$ ) is disordered at the four positions by the crystallographic $\mathrm{C} 4$ axis, and was refined as 0.25 . The other $\mathrm{Br}^{-}$was located between the $\mathrm{Cu}^{\mathrm{II}}{ }_{2} \mathrm{~L}_{4}$ cages without significant interactions with the cationic cage.

a)

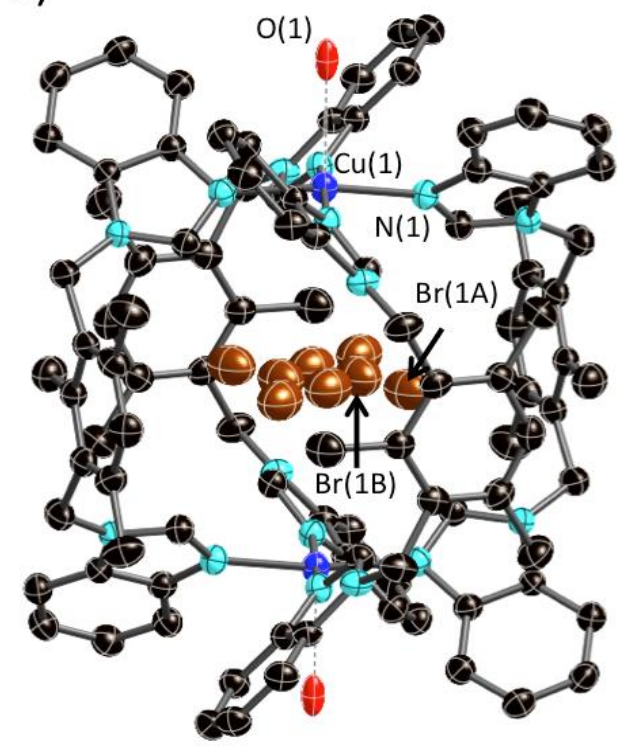

b)

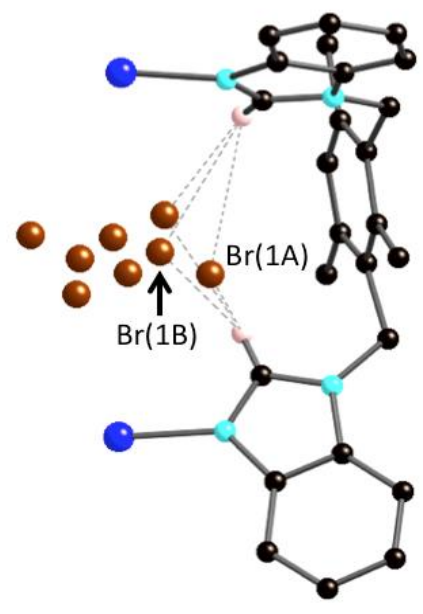

Figure 2. Thermal ellipsoids of the molecular structure of the cationic part of $\mathbf{1 b}$ at $30 \%$ probabilities (a). View of the arrangement of disordered $\mathrm{Br}^{-}$in the cage, and $\mathrm{Br}^{-} \cdots \mathrm{H}-\mathrm{C}$ interactions for $\operatorname{Br}(1 \mathrm{~A})$ and $\operatorname{Br}(1 \mathrm{~B})$ (b). Hydrogen atoms, except for $\mathrm{H}(1)$ in (b), are omitted for clarity. Color code: blue, copper; red, oxygen; brown, bromine; cyan, nitrogen; black, carbon.

Syntheses and structures of $\mathbf{2 a}$ and $\mathbf{2 b}$. Compounds $\mathbf{2 a}$ and $\mathbf{2 b}$ were obtained by the treatment of $\mathrm{CuSO}_{4} \cdot 5 \mathrm{H}_{2} \mathrm{O}$ with $m$-bbitrb and $\mathrm{NaCl}$ (2a) or $\mathrm{NaBr}$ (2b). Single-crystal X-ray diffraction studies and elemental analyses demonstrated that these two compounds are 
constructed by the cationic part $\left[\mathrm{SO}_{4} \subset \mathrm{Cu}_{2}(m \text {-bbitrb })_{4}\right]^{2+}$ and the counter anions $\mathrm{Cl}^{-}$or $\mathrm{Br}^{-}$. These two compounds were isolated from an $\mathrm{EtOH} / \mathrm{H}_{2} \mathrm{O}(1 / 1 ; \mathrm{v} / \mathrm{v})$ solution of $\mathrm{CuSO}_{4} \cdot 5 \mathrm{H}_{2} \mathrm{O}$, $m$-bbitrb, and the inorganic salt $\mathrm{NaCl}$ or $\mathrm{NaBr}$. Results indicated that the space outside the cationic cage $\left[\mathrm{SO}_{4} \subset \mathrm{Cu}_{2}(m \text {-bbitrb })_{4}\right]^{2+}$ has higher affinity for $\mathrm{Cl}^{-}$and $\mathrm{Br}^{-}$than for $\mathrm{SO}_{4}{ }^{2-}$. Compounds $\mathbf{2} \mathbf{a}$ and $\mathbf{2} \mathbf{b}$ are crystallographically isostructural. As resolution of the structure of $\mathbf{2 b}$ was of higher quality, we will use the structure of this compound for our description of the structure.

Figure 3 shows the molecular structure of $\mathbf{2} \mathbf{b}$, which crystallized in the tetragonal space group (P4/ncc, \# 130). The crystallographic $\mathrm{C} 4$ axis runs through the two $\mathrm{Cu}^{\mathrm{II}}$ atoms in the cage framework and the two $\mathrm{Cu}^{\mathrm{II}}$ ions are connected by four $m$-bbitrb. The obtained cationic cage incorporates a $\mathrm{SO}_{4}{ }^{2-}$, which is disordered by the imposed $\mathrm{C} 4$ axis. The structure of this cationic part is essentially the same as in $\mathbf{2 c}$ and $\mathbf{2 d} .^{23}$ The $\mathrm{SO}_{4}{ }^{2-}$ in the cage is coordinated to the two $\mathrm{Cu}^{\mathrm{II}}$ ions $(\mathrm{Cu}(1)-\mathrm{O}(1)=2.173(5), \mathrm{Cu}(2)-\mathrm{O}(2)=2.164(5) \AA)$. The two counter anions per one cationic cage $(\operatorname{Br}(1)$ and $\operatorname{Br}(2))$ are included among the cationic cages. This compound also includes a water molecule, which is disordered at the two positions, among the cages. The water molecule was refined as 0.25 and 0.125 for $\mathrm{O}(5 \mathrm{~A})$ and $\mathrm{O}(5 \mathrm{~B})$. For the two $\mathrm{Br}^{-}, \mathrm{Br}(2)$ forms hydrogen bonds with the water molecule as shown in $3(\operatorname{Br}(2) \cdots \mathrm{O}(5 \mathrm{~A})=3.43(4) \AA$ and $\operatorname{Br}(2) \cdots \mathrm{O}(5 \mathrm{~B})=3.17(4) \AA)$.

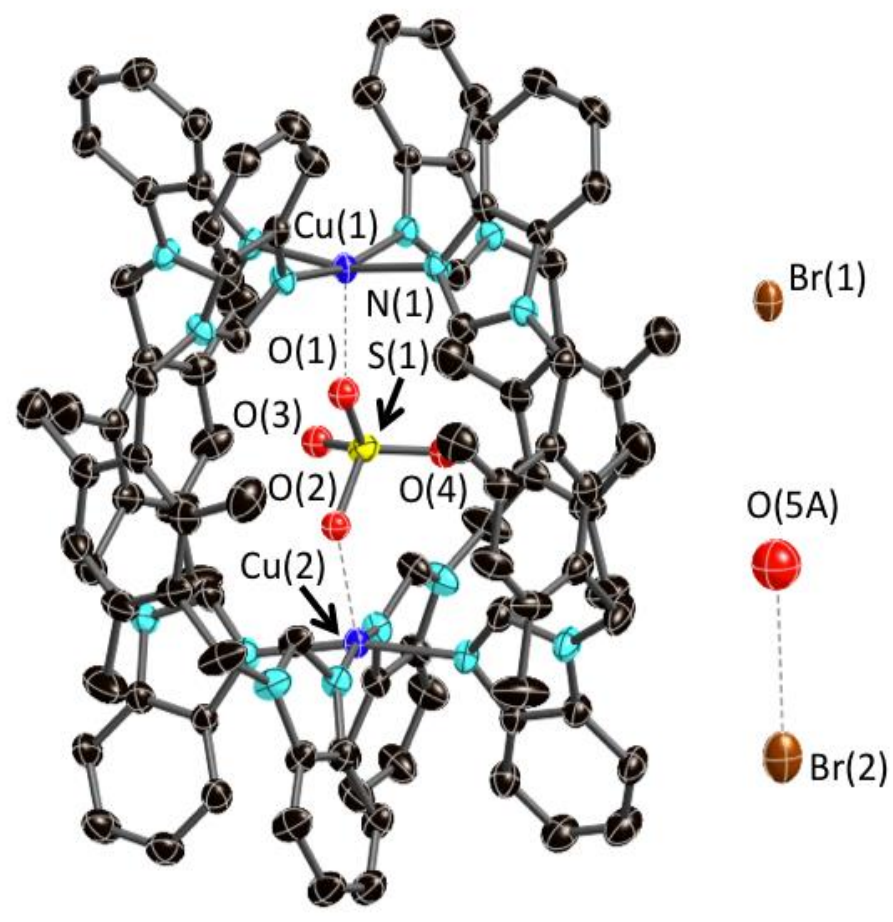

Figure 3. Thermal ellipsoids of the molecular structure of $\mathbf{2 b}$ at $30 \%$ probabilities. Disorders of 
$\mathrm{SO}_{4}{ }^{2-}$, disordered water molecules, and hydrogen atoms are omitted for clarity. Color code: blue, copper; yellow, sulfur; red, oxygen; cyan, nitrogen; black, carbon.

Perchlorate removal by $1 \mathbf{1 a}, \mathbf{1 b}, \mathbf{2 a}$, and $\mathbf{2 b}$. The four compounds prepared in this work (1a, 1b, 2a, and $\mathbf{2 b})$ are insoluble in water. Perchlorate removal from aqueous solutions by the four compounds was studied. Figure 4 shows the change in concentration of $\mathrm{ClO}_{4}^{-}(1.0 \mathrm{mM})$ in aqueous solutions $(100 \mathrm{~mL})$ of $\mathrm{NaClO}_{4}(0.10 \mathrm{mmol})$ after the addition of well-ground powder samples of each of the compounds $(0.10 \mathrm{mmol})$. The change in the concentration of the anions in each of the solutions was determined by ion chromatography. The figure clearly shows that all the compounds reduced the concentration of $\mathrm{ClO}_{4}{ }^{-}$in aqueous solution significantly and that the compounds had comparable activities. For all treatments, the release of $\mathrm{Cl}^{-}(\mathbf{1 a}, \mathbf{2 a}) \mathrm{or}^{-}$ $(\mathbf{1 b}, \mathbf{2 b})$ was observed in response to the removal of $\mathrm{ClO}_{4}^{-}$(Figure 4). In the experiments, the concentrations of $\mathrm{ClO}_{4}^{-}$at $180 \mathrm{~min}$ were $0.30 \mathrm{mM}, 0.32 \mathrm{mM}$, and $0.38 \mathrm{mM}$ for $\mathbf{1 b}, \mathbf{2 a}$, and $\mathbf{2 b}$, respectively. Although their activity would be affected by the particle size, compound $\mathbf{1 a}$ had the highest activity for $\mathrm{ClO}_{4}^{-}$removal among the four compounds investigated. In the experiment, the concentration of $\mathrm{Cl}^{-}\left(\mathrm{Cl}^{-}\right.$was not included in the initial solution) was observed at $10 \mathrm{~min}$ $(0.37 \mathrm{mM})$, and then increased to $0.83 \mathrm{mM}$ at $180 \mathrm{~min}$. For example, in the case of $\mathbf{1 a}, 1.0 \mathrm{mM}$ of $\mathrm{ClO}_{4}^{-}$was reduced to $0.44 \mathrm{mM}$ at $30 \mathrm{~min}$ and then to $0.27 \mathrm{mM}$ at $180 \mathrm{~min}$. These results indicated that the obtained cage compounds removed $\mathrm{ClO}_{4}^{-}$by anion-exchange reactions.

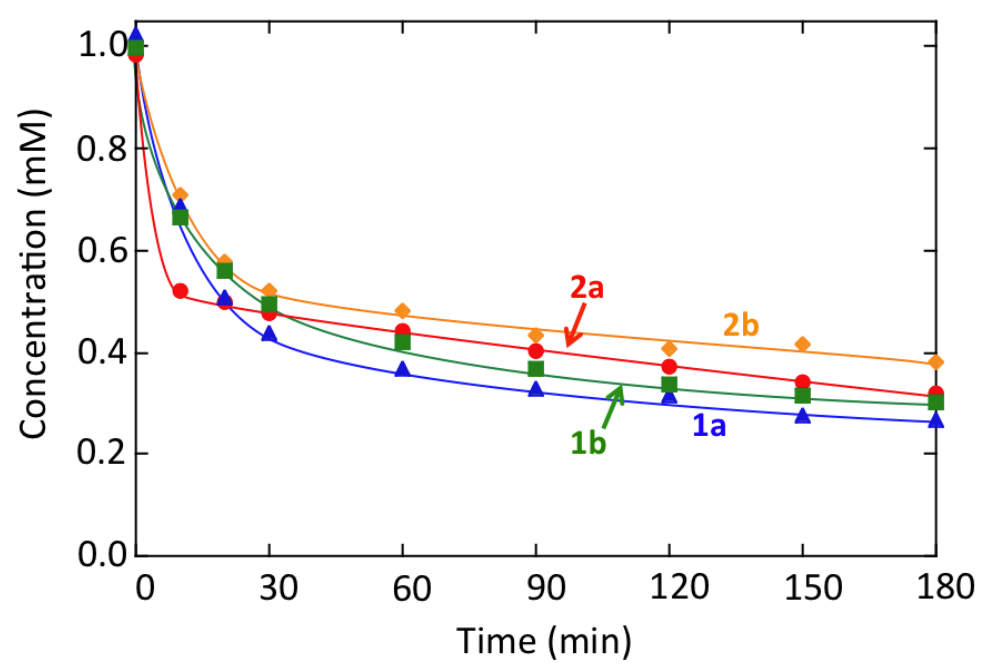

Figure 4. Change in concentrations of $\mathrm{ClO}_{4}^{-}$over time in aqueous solutions $(100 \mathrm{~mL})$ after addition of each of the cage compounds $(0.1 \mathrm{mmol})$. Color code: $\mathbf{1 a}$ (blue), $\mathbf{1 b}$ (green), $\mathbf{2 a}$ (red), and $\mathbf{2 b}$ (orange).

We also studied the anion removal selectivity of $\mathbf{1 a}$ in aqueous solutions. Figure 5 
shows changes in the concentrations of anions depending on the time after addition of $\mathbf{1 a}(0.10$ mmol) in aqueous solutions (100 mL) containing $\mathrm{NaF}, \mathrm{NaCl}, \mathrm{NaBr}, \mathrm{NaNO}_{3}, \mathrm{NaClO}_{4}$, and $\mathrm{Na}_{2} \mathrm{SO}_{4}$ (all $1.0 \mathrm{mM}$ ). The $\mathrm{ClO}_{4}{ }^{-}$was removed preferentially; it was reduced from $1.0 \mathrm{mM}$ to $0.63 \mathrm{mM}$ at $30 \mathrm{~min}$ and then to $0.41 \mathrm{mM}$ at $180 \mathrm{~min}$. The other anions, $\mathrm{NO}_{3}^{-}, \mathrm{NO}_{2}^{-}$, and $\mathrm{Br}^{-}$, were also significantly reduced, from $1.00 \mathrm{mM}$ to $0.79 \mathrm{mM}, 0.88 \mathrm{mM}$, and $0.93 \mathrm{mM}$, respectively, at $180 \mathrm{~min}$. Concentrations of $\mathrm{F}^{-}$and $\mathrm{SO}_{4}{ }^{2-}$ were essentially not reduced. The concentration of $\mathrm{Cl}^{-}$increased from $1.00 \mathrm{mM}$ to $2.10 \mathrm{mM}$ at $180 \mathrm{~min}$ due to the release from $\mathbf{1 a}$ by exchange with the anions removed. The total amount of anions reduced from the aqueous solutions was about $0.10 \mathrm{mmol}$. This value is close to the amount of $\mathrm{Cl}^{-}$released $(0.11 \mathrm{mmol})$. Compound $\mathbf{1 b}$ showed similar anion removal selectivity to that of 1a (Figure S3 in ESI). The removal selectivity of $\mathbf{1 a}$ and $\mathbf{1} \mathbf{b}$ is similar to that of $\mathbf{2} \mathbf{c}: \mathrm{ClO}_{4}^{-}>\mathrm{NO}_{3}^{-}>\mathrm{Br}^{-}>\mathrm{F}^{-}$.

Although $\mathbf{2 a}, \mathbf{2 b}$, and $\mathbf{2 c}$ have the same cationic part $\left[\mathrm{SO}_{4} \subset \mathrm{Cu}_{2}(m \text {-bbitrb })_{4}\right]^{2+}$, their $\mathrm{ClO}_{4}^{-}$removal activity differs. Compound $2 \mathrm{c}$ showed remarkably high activity. This result indicated that the $\mathrm{ClO}_{4}{ }^{-}$removal activity is affected by the types of counter anions that are exchanged with $\mathrm{ClO}_{4}^{-}$. As the anion removal reaction proceeds under heterogeneous conditions, the $\mathrm{SO}_{4}{ }^{2-}$, being larger in size than $\mathrm{Cl}^{-}$or $\mathrm{Br}^{-}$, would provide more space for the incorporation of $\mathrm{ClO}_{4}^{-}$.

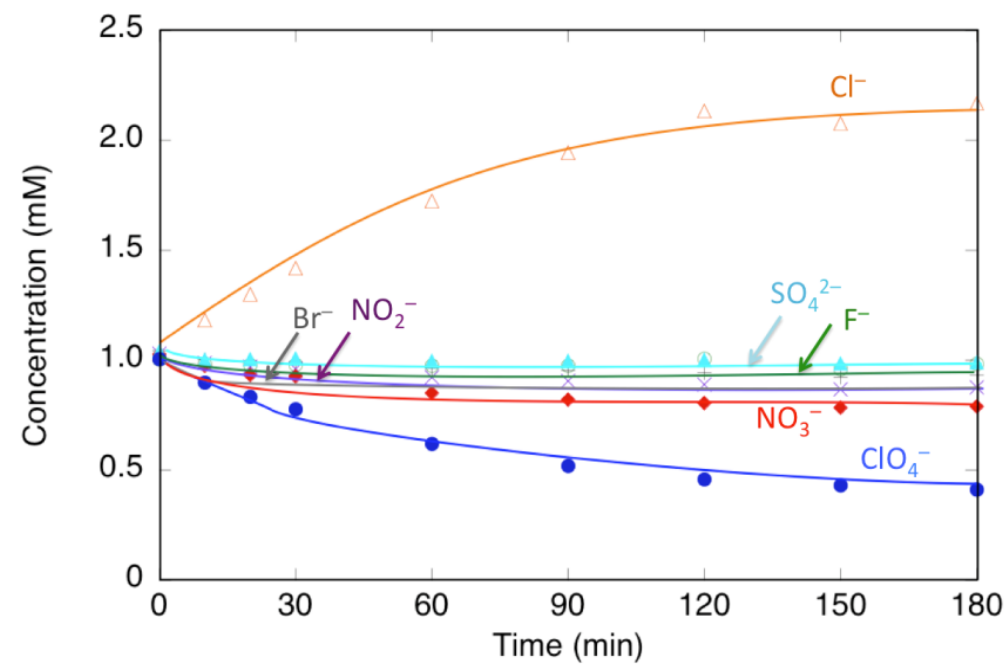

Figure 5. Change in concentrations of anions over time in aqueous solutions (100 $\mathrm{mL})$ containing $\mathrm{NaF}, \mathrm{NaCl}, \mathrm{NaBr}, \mathrm{NaNO}_{3}, \mathrm{NaClO}_{4}$, and $\mathrm{Na}_{2} \mathrm{SO}_{4}$ (all $0.1 \mathrm{mmol}$ ) after the addition of 1a $(0.1 \mathrm{mmol})$. Color code: orange, $\mathrm{Cl}^{-}$; cyan, $\mathrm{SO}_{4}{ }^{2-}$; green, $\mathrm{F}^{-}$; purple, $\mathrm{NO}_{2}{ }^{-}$; gray, $\mathrm{Br}^{-}$; red, $\mathrm{NO}_{3}^{-}$; blue, $\mathrm{ClO}_{4}^{-}$.

Exchange of anions inside and outside the cage. Our previous works and this work show that cationic $\mathrm{M}_{2} \mathrm{~L}^{\mathrm{B}}{ }_{4}$ cage-type compounds remove $\mathrm{ClO}_{4}^{-}$preferentially from aqueous 
solutions by incorporating the anion inside the cage, or including anion among the cationic cages. To study the affinity of the space created by the cationic cage $\left[\mathrm{Cu}_{2}(m-b b i t r b)_{4}\right]^{4+}$ toward anions, we studied the exchange of $\mathrm{SO}_{4}{ }^{2-}$ inside the cage, with $\mathrm{ClO}_{4}^{-}$located outside the cage, using 2d. Figure 6 shows the following for $\mathbf{2 d}$ and $\left[\mathrm{ClO}_{4} \subset \mathrm{Cu}_{2}(m \text {-bbitrb })_{4}\left(\mathrm{ClO}_{4}\right)_{2}\right] \mathrm{ClO}_{4}$ : (a) solid-state reflectance spectra, and (b and c) absorption spectra in $\mathrm{MeCN}$ and $\mathrm{MeCN} / \mathrm{H}_{2} \mathrm{O}$.

In Figure 6a, 2d and $\left[\mathrm{ClO}_{4} \subset \mathrm{Cu}_{2}(m \text {-bbitrb })_{4}\left(\mathrm{ClO}_{4}\right)_{2}\right] \mathrm{ClO}_{4}$ exhibit d-d absorptions in the solid state at $\lambda_{\max }=628$ and $568 \mathrm{~nm}$, respectively. The $\mathrm{Cu}^{\mathrm{II}}$ center of $\left[\mathrm{ClO}_{4} \subset\right.$ $\left.\mathrm{Cu}_{2}(m \text {-bbitrb })_{4}\left(\mathrm{ClO}_{4}\right)_{2}\right] \mathrm{ClO}_{4}$ is based on the elongated octahedral geometry with four imidazole nitrogen atoms at the equatorial positions and two oxygen atoms of $\mathrm{ClO}_{4}{ }^{-}$at the axial positions. The higher $d-d$ absorption energy of this compound is the result of the increased $d_{x} 2-y 2$ orbital due to the weak crystal field of $\mathrm{ClO}_{4}^{-}$.

The $\lambda_{\max }$ of $\left[\mathrm{ClO}_{4} \subset \mathrm{Cu}_{2}(m \text {-bbitrb })_{4}\left(\mathrm{ClO}_{4}\right)_{2}\right] \mathrm{ClO}_{4}$ was observed at $573 \mathrm{~nm}$ in $\mathrm{MeCN}$ and $\mathrm{MeCN} / \mathrm{H}_{2} \mathrm{O}$ (Figure $6 \mathrm{~b}$ and $6 \mathrm{c}$ ). Here, the $\mathrm{d}-\mathrm{d}$ absorption shifted $5 \mathrm{~nm}$ to a longer wavelength compared with that in the solid-state spectrum $(568 \mathrm{~nm})$, and the $\lambda_{\max }$ is quite different to that of $\mathbf{2 d}$, which exhibited a $\lambda_{\max }=629 \mathrm{~nm}$. This indicates that $\mathrm{ClO}_{4}^{-}$is retained in the $\left[\mathrm{Cu}_{2}{ }_{2}(m \text {-bbitrb })_{4}\right]^{4+}$ cage in $\mathrm{MeCN}$ and in $\mathrm{MeCN} / \mathrm{H}_{2} \mathrm{O}$. 
a)

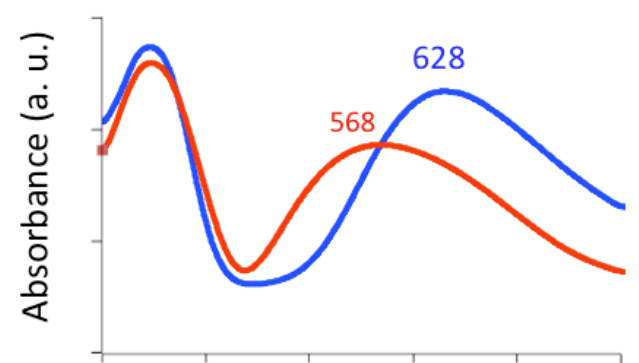

b)

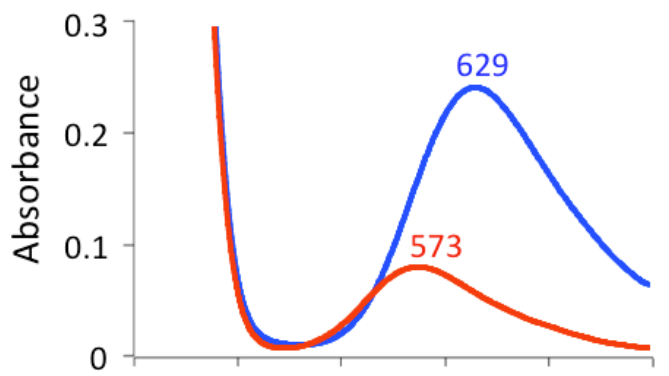

c)

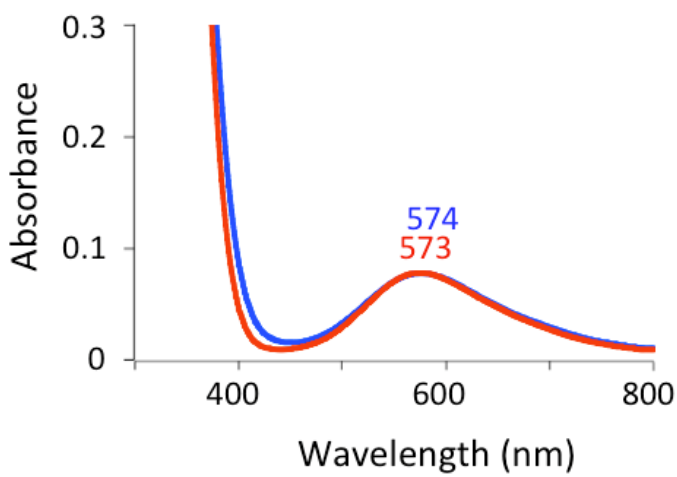

Figure 6. Solid-state reflectance spectra (a) and absorption spectra in $\mathrm{MeCN}(1.0 \mathrm{mM})$ (b) and $\mathrm{MeCN} / \mathrm{H}_{2} \mathrm{O}(\mathrm{v} / \mathrm{v} ; 1 / 1)(1.0 \mathrm{mM})$ (c) for $\mathbf{2 d}$ (blue) and $\left[\mathrm{ClO}_{4} \subset \mathrm{Cu}_{2}(m \text {-bbitrb })_{4}\left(\mathrm{ClO}_{4}\right)_{2}\right] \mathrm{ClO}_{4}$ (red).

For $\mathbf{2 d}$, the $\lambda_{\max }$ of the spectrum in MeCN solution (629 nm, Figure $6 \mathrm{~b}$ ) is similar to that of the solid-state reflectance spectrum; yet, when measured in $\mathrm{MeCN} / \mathrm{H}_{2} \mathrm{O}$, the $\lambda_{\max }$ is remarkably shifted to a shorter wavelength $(574 \mathrm{~nm}$, Figure 6c). Figure $6 \mathrm{c}$ shows that the spectrum of $\mathbf{2 d}$ in $\mathrm{MeCN} / \mathrm{H}_{2} \mathrm{O}$ is quite similar to that of $\left[\mathrm{ClO}_{4} \subset \mathrm{Cu}_{2}(m \text {-bbitrb })_{4}\left(\mathrm{ClO}_{4}\right)_{2}\right] \mathrm{ClO}_{4}$. This result indicated that $\mathrm{SO}_{4}{ }^{2-}$ in the $\left[\mathrm{Cu}_{2}{ }^{\mathrm{II}}(m \text {-bbitrb })_{4}\right]^{4+}$ cage is not exchanged with $\mathrm{ClO}_{4}{ }^{-}$in $\mathrm{MeCN}$, but is exchanged with the anion in $\mathrm{MeCN} / \mathrm{H}_{2} \mathrm{O}$. This reaction is illustrated schematically in Scheme 2. 


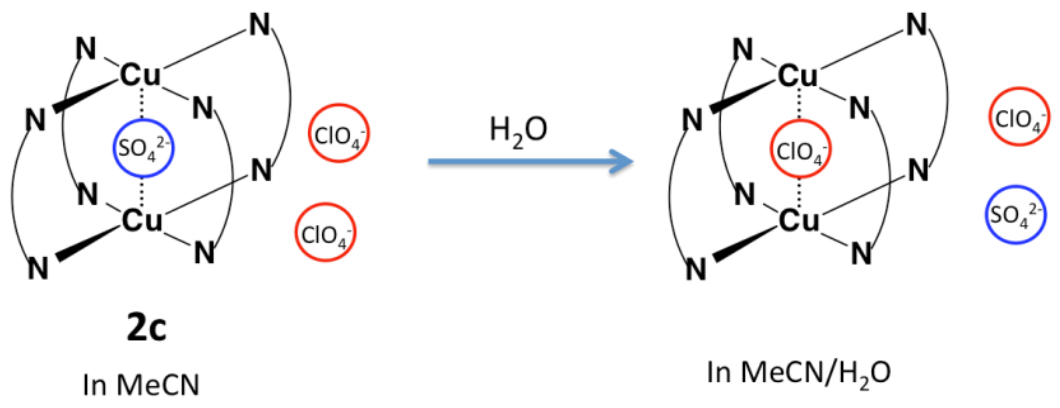

Scheme 2. Schematic illustration of the exchange of $\mathrm{SO}_{4}{ }^{2-}$ inside the cage with $\mathrm{ClO}_{4}{ }^{-}$outside the cage in response to an increase in the hydrophilicity of the solution.

To confirm this anion-exchange reaction, we measured the ESI-TOF mass spectrum of 2d in $\mathrm{MeCN}$ and $\mathrm{MeCN} / \mathrm{H}_{2} \mathrm{O}$ (Figure 7). In MeCN solution, 2d showed two intense peaks, assigned to $\left[\mathrm{SO}_{4} \subset \mathrm{Cu}_{2}(m \text {-bbitrb })_{4}\right]^{2+}$ and $\left[\mathrm{SO}_{4} \subset \mathrm{Cu}_{2}(m \text {-bbitrb) })_{3}\right]^{2+}$ at $\mathrm{m} / \mathrm{z} 872.3$ (Calcd 872.3) and $\mathrm{m} / \mathrm{z} 682.2$ (Calcd 682.2). In $\mathrm{MeCN} / \mathrm{H}_{2} \mathrm{O}$, these two intense peaks were not observed; there were intense peaks at $\mathrm{m} / \mathrm{z} 923.2$ and $\mathrm{m} / \mathrm{z} 582.5$, assigned to $\left[\mathrm{ClO}_{4} \subset \mathrm{Cu}_{2}(m \text {-bbitrb })_{4}\left(\mathrm{ClO}_{4}\right)\right]^{2+}$ (Calcd 923.3) and $\left[\mathrm{ClO}_{4} \subset \mathrm{Cu}_{2}(m \text {-bbitrb })_{4}\right]^{3+}(\mathrm{Calcd} 582.5)$. These results are consistent with the anion-exchange reaction illustrated in Scheme 2, and proposed based on the results of the absorption spectra change mentioned above.

The space in the cationic cage is hydrophobic because it is surrounded by the hydrophobic ligands $m$-bbitrb. While $\mathrm{ClO}_{4}{ }^{-}$has a highly hydrophobic surface, $\mathrm{SO}_{4}{ }^{2-}$ is a typical hydrophilic anion. ${ }^{29}$ Despite the hydrophilicity of $\mathrm{SO}_{4}{ }^{2-}$, this anion is incorporated into the hydrophobic cage by forming coordination bonds to the two $\mathrm{Cu}^{\mathrm{II}}$ centers. Although the solid-state structure of $\mathbf{2 d}$ is retained in $\mathrm{MeCN}$, an increase in hydrophilicity of the solution upon the addition of $\mathrm{H}_{2} \mathrm{O}$ causes the exchange of $\mathrm{ClO}_{4}{ }^{-}$outside the cage, with the hydrophilic $\mathrm{SO}_{4}{ }^{2-}$ inside the cage. This is because the hydrophobic $\mathrm{ClO}_{4}{ }^{-}$has a higher affinity in the hydrophobic space inside the cage than the hydrophilic space created by addition of $\mathrm{H}_{2} \mathrm{O}$ outside the cage. In the solid state, or in $\mathrm{MeCN}$ solution, the spaces created inside and outside the $\left[\mathrm{Cu}_{2}{ }_{2}(m \text {-bbitrb })_{4}\right]^{4+}$ cage are both hydrophobic. Therefore, when the water-insoluble $2 \mathrm{c}$ comes into contact with $\mathrm{ClO}_{4}^{-}$in aqueous solution, $\mathrm{ClO}_{4}{ }^{-}$is incorporated into the hydrophobic space created among the cages, and then the hydrophilic $\mathrm{SO}_{4}{ }^{2-}$ is released to the aqueous solution. 


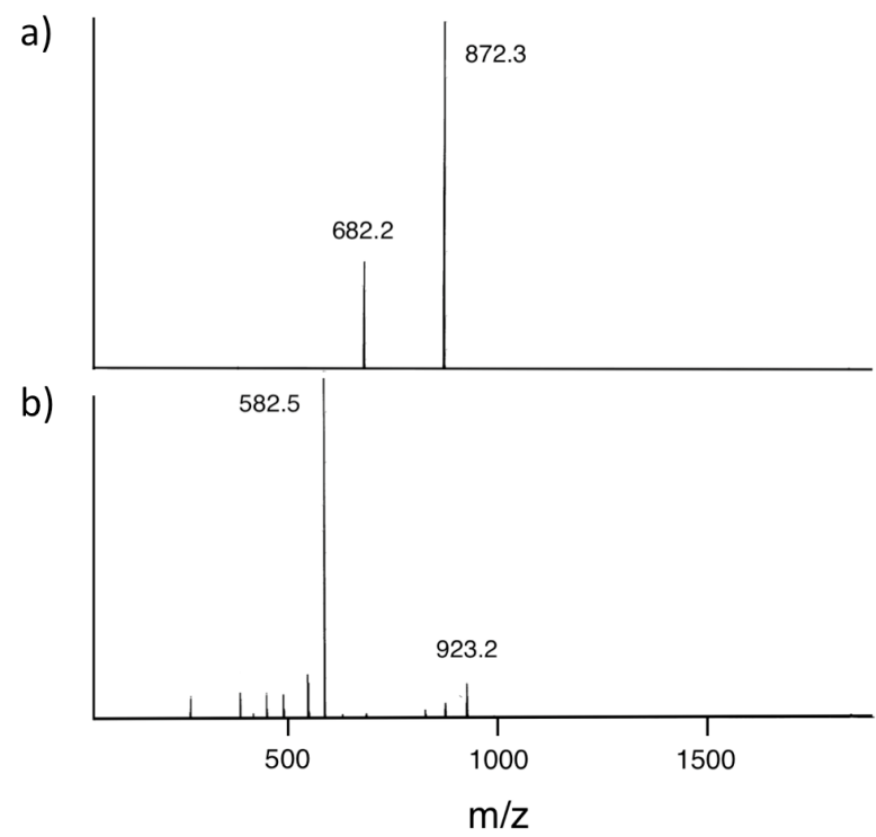

Figure 7. ESI-TOF mass spectra of $\mathbf{2 d}$ measured in $\mathrm{MeCN}$ (a) and $\left.\mathrm{MeCN} / \mathrm{H}_{2} \mathrm{O}(1: 1, \mathrm{v} / \mathrm{v})(\mathrm{b})\right)$.

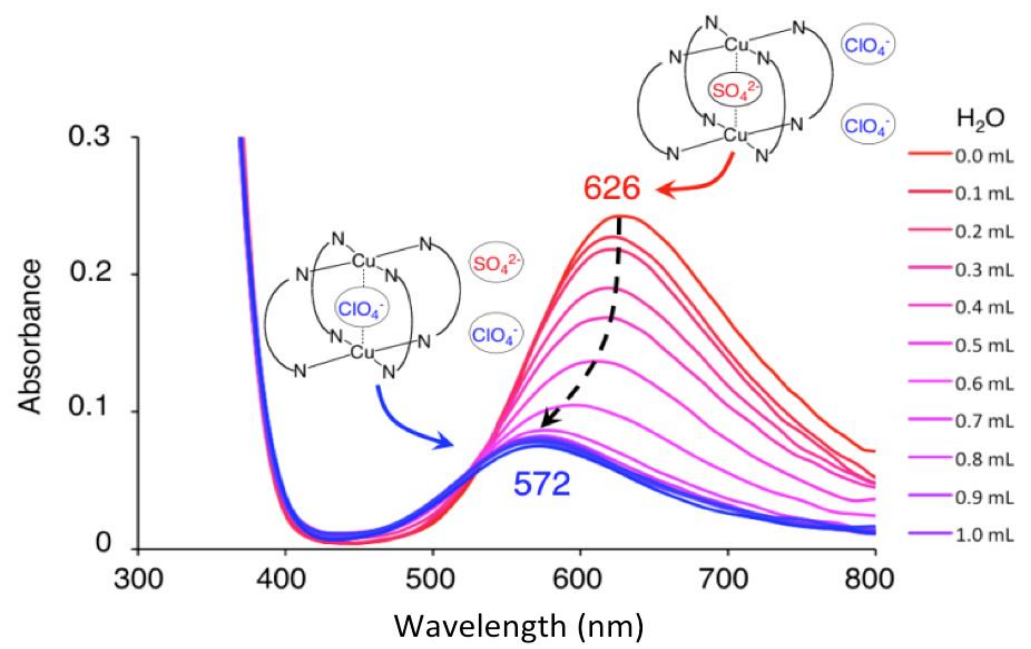

Figure 8. Absorption titration spectra of $\mathbf{2 d}$ in $\mathrm{MeCN}(2.0 \mathrm{~mL})$ upon sequential addition of 0.1 $\mathrm{mL}$ aliquots of water.

We also monitored changes in the absorption spectrum of a MeCN solution of $\mathbf{2 d}$ after the sequential addition of aliquots $(0.1 \mathrm{~mL})$ of $\mathrm{H}_{2} \mathrm{O}$ (see Figure 8 ). The intensity of absorption at $\lambda_{\max }=629 \mathrm{~nm}$ was reduced; it gradually shifted to the higher energy region upon the addition of $\mathrm{H}_{2} \mathrm{O}$. Change in the absorption spectrum essentially ceased when $0.8 \mathrm{~mL} \mathrm{H}_{2} \mathrm{O}$ was added to 2.0 $\mathrm{mL}$ MeCN solution. The absorption spectrum finally obtained was consistent with that of $\left[\mathrm{ClO}_{4}\right.$ $\left.\subset \mathrm{Cu}_{2}(m \text {-bbitrb })_{4}\left(\mathrm{ClO}_{4}\right)_{2}\right]\left(\mathrm{ClO}_{4}\right)$, indicating that the anions are exchanged fully when about $30 \%$ 
$\mathrm{H}_{2} \mathrm{O}$ was present in the $\mathrm{MeCN}$ solution.

\section{Conclusions}

In summary, we have synthesized and characterized four new $\mathrm{Cu}_{2}{ }_{2} \mathrm{~L}_{4}{ }_{4}$-type compounds. Compounds $\mathbf{1 a}$ and $\mathbf{1 b}$ incorporate $\mathrm{Cl}^{-}$or $\mathrm{Br}^{-}$in the cationic cages, while $\mathbf{2 a}$ and $\mathbf{2 b}$ incorporate $\mathrm{SO}_{4}{ }^{2-}$ in the cages. These four compounds contain $\mathrm{Cl}^{-}$or $\mathrm{Br}^{-}$as the counter anions outside the cage; they also exhibited $\mathrm{ClO}_{4}{ }^{-}$removal activity from aqueous solutions by anion-exchange reactions. Compounds $\mathbf{1 a}$ and $\mathbf{1 b}$ exhibited preferential removal of $\mathrm{ClO}_{4}{ }^{-}$from aqueous solutions. The effect of hydrophilicity of the solvent on the affinity of the $\left[\mathrm{Cu}_{2}{ }_{2}(m \text {-bbitrb })_{4}\right]^{4+}$ cage for the anions located inside and outside the cage was studied using $\mathbf{2 d}$. Results of absorption studies and ESI-TOF mass spectra for $2 \mathbf{d}$ indicated that $\mathrm{SO}_{4}{ }^{2-}$ inside the cage and $\mathrm{ClO}_{4}{ }^{-}$outside the cage of $\mathbf{2 d}$ were retained in $\mathrm{MeCN}$, but exchanged in $\mathrm{MeCN} / \mathrm{H}_{2} \mathrm{O}$. This is because an increase in the hydrophilicity of the solution promotes the incorporation of hydrophobic $\mathrm{ClO}_{4}^{-}$into the hydrophobic cage. Preferential removal of $\mathrm{ClO}_{4}^{-}$would be the result of the preferential inclusion of $\mathrm{ClO}_{4}^{-}$into the hydrophobic space created among the cages in the solid state.

\section{Acknowledgements}

M. K. thanks Prof. S. Tachiyashiki of Kagawa Nutrition University for his helpful discussion concerning interaction of $\mathrm{ClO}_{4}^{-}$with the cationic cages . This work was supported by the JSPS Grant-in-Aid for Scientific Research (C) (No. 15K05450).

\section{Notes and references}

1. M. Staffilani, K. S. B. Hancock, J. W. Steed, K. T. Holman, J. L. Atwood, R. K. Juneja and R. S. Burkhalter, J. Am. Chem. Soc., 1997, 119, 6324-6335.

2. R. Vilar, M. P. Mingos, A. J. P. White and D. J. Williams, Chem. Comm., 1999, 229-230.

3. N. Takeda, K. Umemoto, K. Yamaguchi and M. Fujita, Nature, 1999, 398, 794-796.

4. K. Umemoto, K. Yamaguchi and M. Fujita, J. Am. Chem. Soc., 2000, 122, 7150-7151.

5. $\quad$ C.-Y. Su, Y.-P. Cai, C.-L. Chen, H.-X. Zhang and B.-S. Kang, J. Chem. Soc., Dalton Trans., 2001, 359-361.

6. P. D. Beer and P. A. Gale, Angew. Chem. Int. Ed., 2001, 40, 486-516.

7. R. L. Paul, Z. R. Bell, J. S. Fleming, J. C. Jeffery, J. A. McCleverty and M. D. Ward, Heteroatom Chemistry, 2002, 13, 567-573.

8. J. Fan, H.-F. Zhu, T. Okamura, W.-Y. Sun, W.-X. Tang and N. Ueyama, Chem. Eur. J., 2003, 9, 4724-4731. 
9. D. Fielder, D. Pagliero, J. L. Brumaghim, R. G. Begman and K. N. Raymond, Inorg. Chem., 2004, 43, 846-848.

10. M. Yoshizawa, K. Ono, K. Kumazawa, T. Kato and M. Fujita, J. Am. Chem. Soc., 2005, 127, 10800-10801.

11. P. A. Gale and R. Quesada, Coord. Chem. Rev., 2006, 250, 3219-3244.

12. B. E. F. Tiedemann and K. N. Raymond, Angew. Chem. Int. Ed., 2006, 45, 83-86.

13. C.-L. Chen, J.-Y. Zhang and C.-Y. Su, Eur. J. Inorg. Chem., 2007, 2997-3010.

14. H. Amouri, C. Desmarets, A. Bettoschi, M. N. Rager, K. Boubekeur, P. Rabu and M. Drillon, Chem. Eur. J., 2007, 13, 5401-5407.

15. N. Kishi, Z. Li, K. Yoza, M. Akita and M. Yoshizawa, J. Am. Chem. Soc., 2011, 133, 11438-11441.

16. R. Chakrabarty, P. S. Mukherjee and P. J. Stang, Chem. Rev., 2011, 111, 6810-6918.

17. F. P. Schmidtchen, in Supramolecular Chemistryt of anions, eds. A. Bianchi, K. Bowan-James and E. García-España, Wiley-VCH, New York, Editon edn., 1997, pp. 79-146.

18. H.-K. Liu, J. Hu, T.-W. Wang, X.-L. Yu, J. Liu and B. Kang, J. Chem. Soc., Dalton Trans., 2001, 3534-3540.

19. C.-Y. Su, Y.-P. Cai, C.-L. Chen, M. D. Smith, W. Kaim and H.-C. zur Loye, J. Am. Chem. Soc., 2003, 125, 8595-8613.

20. H.-K. Liu, Y. Cai, W. Luo, F. Tong, C. You, S. Lü, X. Huang, H.-Y. Ye, F. Su and X. Wang, Inorg. Chem. Commun., 2009, 12, 457-460.

21. T. Hirakawa, M. Yamaguchi, N. Ito, M. Miyazawa, N. Nishina, M. Kondo, R. Ikeya, S. Yasue, K. Maeda and F. Uchida, Chem. Lett., 2009, 38, 290-291.

22. M. Yamaguchi, T. Hirakawa, N. Nishina, M. Kondo, H. Aoki, E. Okuda and L. Zhang, Chem. Lett., 2010, 39, 1192-1193.

23. M. Mochizuki, T. Inoue, K. Yamanishi, S. Koike, M. Kondo, L. Zhang and H. Aoki, Dalton Trans., 2014, 43, 17924-17927.

24. H.-K. Liu, C.-Y. Su, C.-M. Qian, J. Liu, H.-Y. Tan and B.-S. Kang, J. Chem. Soc., Dalton Trans., 2001, 1167-1168.

25. S. Koike, T. Hirakawa, K. Yamanishi and M. Kondo, Dalton Trans., 2014, 43, 1283212835 .

26. T. Inoue, K. Yamanishi and M. Kondo, Inorg. Chem., 2013, 52, 4765-4767.

27. J. Wolff, Pharmacol. Rev., 1998, 50, 89-105.

28. J. Wolff, Physiol Rev, 1964, 44, 45-90.

29. E. T. Urbansky, Environ. Sci. Pollut. Res., 2002, 9, 187-192. 
30. J. V. Dyke, K. Ito, T. Obitsu, Y. Hisamatsu, P. K. Dasgupta and B. C. Blount, Environ. Sci. Technol., 2007, 41, 88-92.

31. D. R. Parker, A. L. Seyfferth and B. K. Reese, Environ. Sci. Technol., 2008, 42, 1465-1471.

32. M. Asami, K. Kosaka and N. Yoshida, J. Health Sci., 2009, 55, 549-553.

33. B. C. Blount, K. U. Alwis, R. B. Jain, B. L. Solomon, J. C. Morrow and W. A. Jackson, Environ. Sci. Technol., 2010, 44, 9564-9570.

34. P. B. Hatzinger, Environ. Sci. Technol., 2005, 39, 239A-247A.

35. V. Amendola, M. Boiocchi, B. Colasson, L. Fabbrizzi, E. Monzani, M.-J. Douton-Rodriguez and C. Spadini, Inorg. Chem., 2008, 47, 4808 - 4816.

36. E. Sone, M. Sato, K. Yamanishi, C. Kamio, H. Takemoto and M. Kondo, Dalton Trans., 2016, 45, 894-898. 